\title{
JNPH
}

Volume 7 No. 1 (April 2019)

(C) The Author(s) 2019

\section{IDENTIFIKASI KETONURIA PADA MAHASISWA OBESITAS DI POLTEKKES KEMENKES BENGKULU PADA TAHUN 2018}

\section{CETONURIA IDENTIFICATION IN OBESITY STUDENTS IN THE POLTEKKES KEMENKES OF BENGKULU IN 2018}

\author{
TEDY FEBRIYANTO \\ JURUSAN ANALIS KESEHATAN \\ Email: tedyfoo01@gmail.com
}

\begin{abstract}
Background: Obesity is defined as a condition of abnormal or excessive accumulation of fat in adipose tissue up to a certain level that can damage health. The high levels of fatty acids that cause the presence of ketones in the urine (Ketonuria) tend to be experienced by people who are obese.Objective: The purpose of this study was to determine the description of ketonuria in obese students in Poltekkes Kemenkes Bengkulu. Research Method:This research is done withdesigndescriptipthat is a research To analyze Ketonuria at Poltekkes Student of Bengkulu Health Ministry in year 2018. The number of sample in this research is 43 people. The sampling method used is total sampling with respondents all students of Obesity in Poltekkes Kemenkes Bengkulu. Result of research: result of research show ketonuria in obese student in Poltekkes Kemenkes bengkulu 1 person with percentage equal to $(2,33 \%)$, while 42 other student negative. Conclusion: Based on the research result of obesity student in Poltekkes Kemenkes Bengkulu in 2018, students should arrange healthy lifestyle and can control themselves to avoid ketonuria.
\end{abstract}

\section{Keywords: Ketone, Ketonuria, Obesity}

\begin{abstract}
ABSTRAK
Latar belakang: Obesitas didefinisikan sebagai suatu kondisi akumulasi lemak yang tidak normal atau berlebihan di jaringan adiposa sampai kadar tertentu sehingga dapat merusak kesehatan. Tingginya kadar asam lemak yang menyebabkan adanya keton dalam urin (Ketonuria) cenderung dialami oleh masyarakat yang obesitas. Tujuan penelitian ini untuk mengetahui gambaran ketonuria pada mahasiswa obesitas di Poltekkes Kemenkes Bengkulu. Metode Penelitian : Penelitian ini dilakukan dengan desain descriptip yaitu suatu penelitian Unt uk menganalisa Ketonuria pada Mahasiswa Poltekkes Kemenkes Bengkulu pada tahun 2018. Jumlah sampel dalam penelitian ini adalah 43 orang. Adapun metode pengambilan sampel yang digunakan adalah total sampling dengan responden seluruh mahasiswa Obesitas di Poltekkes Kemenkes Bengkulu. Hasil penelitian: hasil penelitian menunjukan ketonuria pada mahasiswa obesitas di poltekkes Kemenkes bengkulu sebanyak 1 orang dengan persentase sebesar (2,33\%), sedangkan 42 mahasiswa lainnya negatif. Kesimpulan: Berdasarkan hasil penelitian mahasiswa obesitas di Poltekkes Kemenkes Bengkulu pada tahun 2018, hendaknya mahasiswa mengatur pola hidup yang sehat dan dapat mengontrol diri agar terhindar dari ketonuria.
\end{abstract}




\section{PENDAHULUAN}

Obesitas juga sangat menonjol di negaranegara berkembang terutama di Indonesia, sekitar $18 \%$ populasi remaja dan lebih $35 \%$ populasi dewasa mempunyai berat badan berlebihan atau obesitas. Sejak tahun 1970 hingga sekarang, kejadian obesitas meningkat dua kali lipat pada anak usia 2-5 tahun dan usia 12-19 tahun, bahkan meningkat tiga kali lipat pada anak usia 6-11 tahun. di Indonesia prevalensi obesitas pada anak usia 6-15 tahun meningkat dari 5\% di tahun 1990 menjadi 16\% di tahun 2001 (Muslim et al., 2015).

Keton merupakan produk dari pemecahan asam lemak. Keberadaan keton dalam urin menandakan bahwa tubuh menggunakan lemak sebagai energi. Pada saat tubuh mengalami kelaparan dimana jumlah karbohidrat tidak mencukupi sebagai energi, asam lemak akan diubah menjadi badan keton yang kemudian beredar dalam darah, proses pembentukan keton disebut sebagai ketogenesis. Suatu keadaan dimana jumlah keton yang diproduksi melebihi jumlah normal disebut sebagai ketosis, yang kemudian dapat ditemukan dalam darah yang dikenal sebagai ketonemia atau dalam urin sebagai ketonuria (Kandou \& Wowor, 2016)

Urinalisis merupakan pemeriksaan urin yang terdiri dari pemeriksaan makroskopik, mikroskopik atau sedimen, dan kimia urin yang dilakukan secara tepat, dapat diandalkan, aman, dan efektif. Pada pemeriksaan kimia digunakan pemeriksaan carik celup yang terdiri dari pemeriksaan $\mathrm{pH}$, berat jenis, protein, glukosa, keton, eritrosit, bilirubin, urobilinogen, nitrit, dan leukosit. Untuk pemeriksaan mikroskopik dilakukan melalui evaluasi sedimen dan hasil sentrifugasi urin. Salah satu komponen dari pemeriksaan urinalisis adalah pemeriksaan kimia keton (Kandou \& Wowor, 2016)

Ada beberapa metoda pemeriksaan urin yang biasa dilakukan, antara lain metoda dipstick atau carik celup dan metoda standar. Pemeriksaan urinalisis yang biasa dilakukan dengan carik celup antara lain: berat jenis, $\mathrm{pH}$, glukosa, protein, keton, darah, bilirubin, urobilinogen, nitrit, leukosit esterase (Nindatu et al., 2012).

Tingginya kadar asam lemak yang menyebabkan adanya keton dalam urin (Ketonuria) cenderung dialami oleh masyarakat yang obesitas. Sehingga peneliti tertarik untuk melakukan penelitian tentang gambaran ketonuria pada mahasiswa yang obesitas di Poltekkes Kemenkes Bengkulu pada tahun 2017 dengan indeks massa tubuh $>27 \mathrm{~kg} / \mathrm{m}^{2}$.

\section{METODE PENELITIAN}

Penelitian ini menggunakan desain Deskriptif yaitu dengan menggunakan strip test urine, dengan melihat perubahan warna yang dihasilkan (orange-ungu tua). Penelitian ini telah dilaksanakan di Laboratorium Terpadu Poltekkes Kemenkes Bengkulu pada bulan Oktober 2017- Mei 2018. Sampel yang digunakan yaitu urine pagi.

\section{HASIL PENELITIAN}

Tabel 1 Prevalensi ketonuria pada mahasiswa obesitas di Poltekkes Kemenkes Bengkulu

\begin{tabular}{ccc}
\hline $\begin{array}{c}\text { Hasil } \\
\text { pemeriksaan }\end{array}$ & Frekuensi & Persentasi \\
\hline Positif & 1 & $2,33 \%$ \\
Negatif & 42 & $97,67 \%$ \\
\hline Total & 43 & $100 \%$ \\
\hline
\end{tabular}

Berdasarkan tabel diatas penelitian tentang identifikasi ketonuria pada mahasiswa obesitas di Poltekkes Kemenkes Bengkulu pada tahun 2018, dari 43 responden mahasiswa obesitas, diperoleh hasil 1 sampel positif ketonuria $(2,33 \%)$ dan 42 sampel negatif ketonuria $(97,67 \%)$ di tandai dengan terjadinya perubahan warna pada strip test urine. 


\section{PEMBAHASAN}

Keton dapat ditemukan pada penderita obesitas karena, Obesitas merupakan keadaan akumulasi lemak yang tidak normal atau berlebihan di jaringan adipose sehingga menyebabkan gangguan metabolik seperti resistensi insulin. Dimana resintensi insulin ini, menyebabkan terjadinya gangguan metabolisme karbohidrat, sehingga energi yang di butuhkan oleh tubuh akan dibentuk melalui metabolisme lemak. Dari proses metabolisme lemak tersebut maka dihasilkan benda keton yang dapat ditemukan dalam urin atau ketonuria (Kusmiati et al., 2015).

Tidak setiap penderita obesitas ditemukan ketonuria, hal ini disebabkan oleh kinerja insulin. dimana insulin bekerja menghambat terjadi lipolysis dan memicu terjadinya lypogenesis. Insulin memicu defosforilasi dari hormone-sensitif lipase dan mengaktifkan lipogenesis dengan menstimulasi asetil CoA karboksilase. Dalam jaringan adiposa, defosforilasi dari hormonisensitif lipase menghambat pemecahan trigliserida menjadi asam lemak dan gliserol. Hal ini menyebabkan penurunan substrat yang tersedia untuk pemecahan lemak (Kandou \& Wowor, 2016).

Keberadaan keton dalam urine tidaklah normal. Keton hanya akan dibentuk saat terjadi defisiensi karbohidrat dan tidak dibentuknya energi dari glukosa. Keton kemudian akan beredar dalam darah dan diedarkan ke seluruh tubuh melalui pembuluh darah dan diedarkan ke seluruh tubuh melalui pembuluh darah menuju organ organ penting seperti otak dan otot dimana keton dibutuhkan sebagai energi pengganti (Kandou \& Wowor, 2016).

Keton bersifat asam, sehingga tubuh akan menghasilkan basa sebagai buffer untuk mempertahankan keseimbangan tubuh. Bila terus-menerus menggunakan keton sebagai energi, suatu saat cadangan basa tubuh akan habis dan hal ini akann menimbulkan kedaruratan yang disebut ketoasidosis yang dapat mengancam nyawa. Inilah dimana pemeriksaan keton pada penderita obesitas
(Kandou \& Wowor, 2016).

Keadaan seperti ketoasidosis diabetik, kelaparan, hamil, ketoasidosis alkoholik, diet tinggi protein rendah karbohidrat, muntah, diare, dan hiperglikemi merupakan keadaankeadaan yang dapat memicu produksi keton dalam tubuh. Badan keton tidak hanya diukur sebagai urinalisis lengkap, tetapi dilakukan untuk mengklarifikasi atau mengobati beberapi populasi pasien seperti pasien yang masuk rumah sakit dalam keadaan darurat, diabetes dengan resistensi insulin yang mutlak, atau pasien dengan komplikasi pada kehamilan. Setelah terapi insulin dan cairan pada hiperglikemi dan ketosis, jaringan bhidroksibutirat diubah kembali menjadi asetoasetat yang menyebabkan peningkatan sementara dari ekskresi asetoasetat di urin meskipun keadaan klinisnya membaik (Kandou \& Wowor, 2016).

\section{KESIMPULAN}

Berdasarkan hasil penelitian tentang identifikasi ketonuria pada mahasiswa obesitas di Poltekkes Kemenkes Bengkulu pada tahun 2018 dari 43 responden mahasiswa obesitas, diperoleh hasil 1 sampel positif ketonuria $(2,33 \%)$ di tandai dengan terjadinya perubahan warna pada strip test urine.

\section{SARAN}

Bagi masyarakat khususnya mahasiswa Poltekkes Kemenkes Bengkulu hendaknya dapat menerapkan pola hidup dan pola makan yang sehat serta mengontrol diri agar terhindar dari ketonuria.

\section{DAFTAR RUJUKAN}

Kandou, P. R. D., \& Wowor, M. (2016). Gambaran glukosa urin pada pasien tuberkulosis paru dewasa, 4, 2-7.

Kusmiati, M., Herdiansyah, K. D., \& Nuraeni, S. (2015). Gambaran Kadar Glukosa dan Kolesterol Total pada Penderita Obesitas Sebelum dan Sesudah 
Mengkonsumsi Minuman Probiotik. Jurnal Kesehatan Bakti Tunas Husada, 14(1), 48-51.

Gandasoebrata. (2004). Penuntun Laboratorium Klinik. In Dian Rakyat (pp. 90-93).

Muslim, A., Analis, J., \& Tanjungkarang, K. P. (2015). Korelasi Pemeriksaan Glukosa Urin Dengan Protein Urin Pada Penderita Diabetes Mellitus Tipe II, 52-56.

Nindatu, M., Tuhumury, N. L., Kaihena mArthaStudi, P., Dokter, P., \& Pattimura, U. (2012). M lluca medica. 